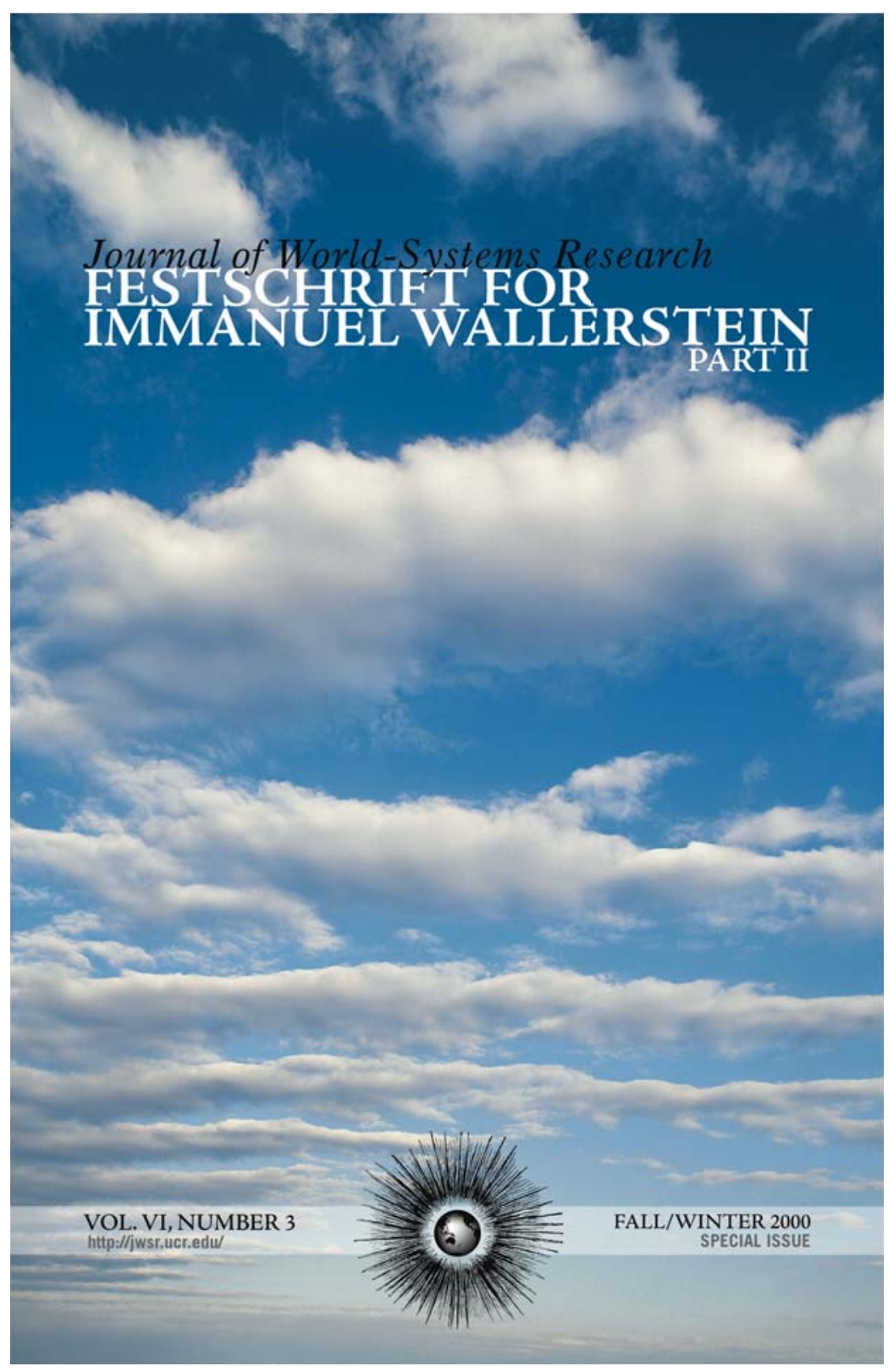

\title{
American Liberalism, One Worldism \& World-Systems Analysis
}

Orlando Lentini

T iberalism is a system of norms and values elaborated by the European world-economy in the course of its constitutive process. It is a matter of organizational principles determining the acting subject, economic action, the state and, the entire picture of social imaginary, starting from the prescriptive nucleus of 'freedom' rights.

The history of liberalism is the story of a methodical structuring of norms and values, which postulates a possessive and acquisitive subject in a system of ceaseless pursuit of endless accumulation. This methodical structuring had already begun in the XIII century with the formation of the Mediterranean world-economy, centered on the free city states of the Italian peninsula. ${ }^{1}$ Initially, the above elaboration utilized elements of ancient both Graeco-Roman and Judaic-Christian organizational experience, but the identification of a new nucleus adequate to the new system was not realized until the XVII century, with the establishment of Dutch hegemony in the world-system and the emerging English organizational power. ${ }^{2}$

From the English revolutions of the XVII century, which inserted the prescriptive nucleus of 'freedoms' in a historiographic picture of republi-

Orlando Lentini

Via Eleonora D'Arborea, 12

Rome, 00162 ITALY

lantini@vm.cised.unina.it

1. See Hans Baron, The Crisis of the Early Italian Renaissance: Civic Humanism and Republican Liberty in an Age of Classicism and Tyranny, Princeton 1966. If the historiography of freedom can start from Machiavelli (see my Analisi sociale machiavelliana, Milan 1992), it is only in XVII century that a true paradigm develops.

2. The works of Thomas Hobbes, Baruch Spinoza and William Petty are emblematical in this process of ideological elaboration, several times later resumed from different perspectives.

JOURNAL OF WORLD-SYSTEMS RESEARCH, VI, 3, FALL/WINTER 2O00, 8I2-826 Special Issue: Festchrift for Immanuel Wallerstein - Part II

http://jwsr.ucr.edu

ISSN I076-I56x

(C) 2000 Orlando Lentini 
canism, ${ }^{3}$ that is a self-government by producers, the elaboration of a new system of norms and values proceeded steadily, to become, in the XVIII century, the core of American emancipation and French revolution. With its extreme wings, socialism and conservatism, liberalism would become, in the XIX century, the central component of the geoculture of the modern world-system. Therefore the system could now rely on a complex of norms and values, always in progress, but endowed with its own specificity, from which new 'structures of the whys' of social knowledges derive.

During a long period roughly spanning from 1650 to 1870 coinciding with the history of the formation of English hegemony in the world-system, a paradigm of social analysis was constituted, which we can call liberal Marxist, the fundamental prescriptive nucleus of which were the 'liberties,' variously defined, according to a growing number of 'rights'. It was not a speculative process but a pragmatic, methodical structuring of organizational values of the core country, which in XIX century would establish its hegemony in the world-system.

Therefore, we should speak of an English liberalism, ${ }^{4}$ with its articulations elaborated in other core countries of the world-economy, notably France, United States and Germany. The American radical, the French atomistic and the German holistic versions served as complements to the English mode, characterized mainly by its system of guarantees of 'rights.'

The liberal-Marxist paradigm was the construction of an analytical imaginary based on the 'liberties,' no longer valid solely for acquisitive proprietors, rather for all the members of a division of labor, and not only in a single central or semiperipheral country, but for all countries of the worldsystem.

The welding of world interdependence and human rights was probably the result of the stimulus of antisystemic forces linked to industrial workers of core countries and found one of its paradigmatic formulations in MarxEngels Communist Manifesto. This was a typical liberal-Marxist product of

See John G. A. Pocock, The Machiavellian Moment. Florentine Political Thought and the Atlantic Republican Tradition, Princeton: Princeton University Press, 1975.

4. On the specificity of an English elaboration of liberal values, cfr. Eugenio Federico Biagini, Progressisti e puritani: aspetti della tradizione liberal-laburista in Gran Bretagna, 1865-1992, Manduria 1995. the phase of English hegemony, when political rights and 'economic rights' were strongly connected. English liberalism, with its liberal-Marxist variants, was hinged on the ideal type of economic operator who, in a market space, exerted their liberties thus enabling the optimal working of the system. This was associated with a 'free trade' and laissez-faire economic theory, which dominated English economic analysis until World War I.

Nevertheless, laissez-faire theory, around the middle of the XIX century, seemed at odds with German interests. Furthermore, even for the political system in a united Germany, the imitation of the hegemonic English organizational experience was problematic. In order to compete in the world-economy it was necessary to promote liberal institutions, but the emphasis was now on 'social state' instead of 'legislation oriented to the individual.' Both public power and the intellectuals in Germany converged on the necessity of a union for social policy, a trend later assumed by all the core countries. The German historical school not only rejected laissez-faire theory, but also ended by elaborating a 'liberalism of the chair', whose subtlest interpreter can be considered Max Weber.

Germany anticipated through Staatswissenschaften the need for systems of social security, which were destined to become an essential part of the 'liberal state.' Indeed between 1870 and 1920, the English model too underwent strong reformist tensions that imposed an updated elaboration of the organizational values, to incorporate new labor 'rights.' Previous laissez-faire and elitist versions survive while the context is dominated by new visions of 'social state' or 'welfare state.'

English liberalism changed together with the liberalism of other core countries and found a settlement with Hobhouse, the systematizer of a version open to the 'social' demands submitted by Labourites. ${ }^{5}$ The attention paid by scholars to the increasing role of Marxism between XIX and XX century, lessened the importance of what appears now to be the main ideological change, i.e. the adaptation of the prescriptive liberal nucleus to the transformation of the capitalist system.

Other European countries appeared more oriented to producing state systems of social security, while the Americans still seemed to advocate the

5. See Leonard T. Hobhouse, Liberalism, London 1911. 
primacy of acquisitive enterprise against any other liberty, despite or perhaps thanks to the persistence of the rhetoric of the legislation oriented to the individual'of federalist origins. ${ }^{6}$

e 'crisis' of a certain version of XIX century English liberalism was not only the final result of changes in power relations between capital and labor in Europe, but was also an indication of a passing of hegemony, the consequence of structural changes in the American system of business enterprises, the formation of an industrial economy dominated by the corporations, i.e. the modern multiunit business enterprises which resulted from the integration of the process of mass production with that of mass distribution within a single business firm? ${ }^{7}$ The rhetoric of the legislation oriented to the individual' now had to come to a compromise with the reality of the dominance of corporations.

'American liberalism,' a liberalism we can now define 'pragmatic by virtue of its capability to adapt to the real organizational development, would be characterized by the acceptance of the corporation, still considered a synonym of monopoly, within the perimeter of its [designated] liberties and rights. ${ }^{8}$ American liberal-democracy acknowledged the maneuver rights of the corporation as well as the right of the political power to determine bounds in defense of liberties and rights of individuals or interest groups. ${ }^{9}$

Berle \& Means' book on modern corporation and private property emblematically marks the passing from the Smithian vision to the 'corporate' one. However Berle does not limit himself to accept the empirical obviousness of the monopolistic concentration of economic power in United States, but he also denounces the separation between property and control in the

6. Alexander Hamilton ( Madison, Jay), The Federalist, New York, Mac Lean 1788.

Alfred D. Chandler, Jr., The Visible Hand: The Managerial Revolution in American Business, Cambridge Mass: Harvard University Press, 1977

8. This passage is recorded in Adolf A. Berle, Jr. and Gardiner C. Means, The Modern Corporation and Private Property, New York 1932. See also Robert Eden, "On the Origins of the Regime of Pragmatic Liberalism: John Dewey, Adolf A. Berle, and FDRs Commonwealth Club Address of 1932," Studies in American Political Development, 7, Spring 1993. As for Berle, its liberalism besides pragmatic, should be defined as corporate; cfr. Jordan A. Schwarz, Liberal. Adolf A. Berle and the Vision of an American Era, New York 1987.

9. See Ellis W. Hawley, The New Deal and the Problem of Monopoly: A Study in Economic Ambi-valence, Princeton 1966. giant corporation, and the tendency of the management to perpetuate its power by excluding the shareholders. So, the liberal assumption of 'legislation oriented to the individual' is once again restated, partly restoring shareholders control, but renouncing to exorcise the giant corporation.

The transition from English liberalism to American liberalism was a gradual process, in which at first English Labourites renegotiated state/ individual relations, ${ }^{10}$ followed by some of the American political intelligentsia, but with decidedly innovative results as a consequence of the organizational implications of the new system of business enterprises developed in the United States. Now the schema was no longer dichotomic but tripartite, because between the individual and the state the giant corporations interposed themselves, becoming 'quasi-states.'

The problem was no longer to create intermediate bodies between individual and state but to acknowledge that the economic power of the country derived from a multiplicity of 'quasi-states,' whose expansion was crucial for the United States' wealth as well as its foreign policy. The meaning of notions like freedom, equality and imperialism now changed. The USA on the one hand inherited organizational values from the most advanced European countries, while on the other hand introduced itself new values.

On the American side a new type of internationalism emerged, which was post-colonial and regulated by the rhetoric of self-determination of peoples or nations. The US international liberals, generally liberal-Labourite in internal policy, were the new progressive figures who would become central in to the political culture of the XX century. It was probably the transnational character of the corporation that created, between the world wars, the culture of international liberalism, oriented to a new vision, called one worldism. This orientation would characterize the cultural investments of the major Foundations, from then on among the main promoters of interior and foreign education programs and oganizational culture based on liberal internationalism.

American liberalism not only rhetorically exalted 'legislation oriented to the individual,' the main matrix of exceptionalism already in Tocqueville's

10. The story of this English mediation in the passing to pragmatic liberalism is Isaac Kramnick and Barry Sheerman, Harold Laski. A Life on the Left, London 1993. 
model, but now aims at spreading this value orientation all over the world. ${ }^{11}$ By so doing, became also necessary the exportation of world New Deal organizational principles, having its engine in The United States and the division of labor they imposed.

One worldism was a typically American ideology, ${ }^{12}$ which however had soon to yield, with the cold war, to two worldism, a tendency in some way answering to persistent isolationist leanings of the moderate public opinion. In a picture of contrasting pressures, for or against 'one world' and, within 'one world,' for or against American hegemony, social knowledges had to face entirely new problems of adjustment to the standard objectivity.

All the analytical work that follows the formation of the modern worldeconomy, reflects the point of view of local intelligentsias, mostly based on 'nation-states,' which also imposed themselves as the main units of analysis. Nevertheless part of the analytical work was devoted to the study of problems the local business enterprises had to face in their transnational range, with a unit of analysis, the 'universal trade,' now called world economy. By weaving between nation-state and world market, American social knowledges achieved the phase of hegemonic rising.

United States realized the world nature of their duties already after World War I. In the social sciences this new situation had been elaborated by several liberals and social democrats with internationalist leanings. The journal The New Republic and the New School for Social Research were, between the two wars, the leading ideological institutions in promoting a

11. For a critical introduction to the historiographicalhistoriographic debate on American exceptionalism, (see Ian Tyrrel, American Exceptionalism in an Age of International History, American Historical Review, 96, oOct. 1991.) A convinced confirmation is on the contrary Seymour Martin Lipset, American Exceptionalism. A Double-Edged Sword, New YorkLondon 1996.

12. This is at least the opinion of Oscar Handlin, One World. The Origin of an American Concept, Oxford 1974. One worldism is in fact the reisult of a new international orientation of the US administration from Woodrow Wilson, that ended in a fundamental agreement between Democrats and Republicans during the World War II; see Wendell L. Willkie, One World, London 1943. As a cultural movement, from 1947 one worldism had its journal, Common Cause, later subtitled A Journal of One World, published by the University of Chicago until 1951. new system of norms and values on world democracy, variously combining the demand of political and economic rights. ${ }^{13}$

New York would be the center of a cultural and political movement expanding and elaborating a system of liberal and internationalist norms and values. This movement involved the progressive wing of Columbia University and its best accomplishment was the Encyclopaedia of the Social Sciences (1930-1934). As a result of the joint effort of the exponents of the rising 'American liberalism' and the most advanced European social science, the Encyclopaedia reflected the analytical climate that would triumph during the New Deal between the two wars. It was the most ambitious collective expression of the aspiration to lay down the bases of the ideological foundation of a world liberal internationalism.

Liberals and social democrats like Seligman, Hobhouse, Johnson, Laski, De Ruggiero, Keynes, Lederer, Schumpeter, Kallen, Berle, Beard, Dewey, Einaudi etc., were united in unique enterprise of liberal-democratic and internationalist definition of world situation, which would be later translated in a solid antifascist alliance (the 'united nations'), with the creation of the UN organization and the foundation of a new world historiography.

Moreover, the Encyclopaedia records the social scientization of social knowledges, now seen as an essential component of the art of government. On the wave of the vision asserted later by the New Deal, the pragmatic social scientist, analytical, more and more documented and oriented to empirical research, produced the knowledges needed for the government of a society of free men. Perhaps it is not a chance that politics would be by then endowed with its own disciplinary apparatus and its 'lassics,' wavering between so-called 'machiavellian' and democratic traditions.

Sociology and political science were now particularly engaged in the effort to set and stabilize the categorial apparatus of political and social action, thus setting in motion the reification of 'American liberalism' dynamics. Even if it was a question of a society whose wealth derived mainly from the corporations, it assured its loyal members room for 'voluntary' action.

13. See Peter M. Rutkoff, William B. Scott, New School. A History of the New School for Social Research, New York 1986. The book illustrates also the crucial role playedby Alvin Johnson and the New School in creatingand editing the Encyclopaedia of the Social Sciences. 
The single 'social actors,' once internalized the central system of norms and values, no longer based on or derived from 'individuals' but objective 'social systems,' would act in full freedom, reproducing a liberal and democratic society. ${ }^{14}$

It was a matter of a new reality where monopoly tendencies and planning policies interlaced, sweeping away romantic individualism and imposing state intervention. The German experience, represented by W. Rathenau and illustrated by Emil Lederer, meets the reflection of A. A. Berle, Alvin Johnson, John Dewey and Harold Laski himself, making the Encyclopaedia the most important product of social analysis between the two wars.

In this period, objectivity seemed guaranteed by methodological strategies and by a supposed identity of interests among the various components of the 'international community', legitimating an abstract universalism, de facto function of western interests, or rather of the core countries of the world-economy. The assertion of liberal values for all human beings and of the rights of peoples, ethnic groups, social classes and stands, minorities and later gender rights, was considered the normal development of the organizational principles of the political and ideological 'revolutions' of XVIII century, whose heritage was claimed by the Americans, who translated their exceptionalism as western exceptionalism.

The combination of New Deal liberalism (democracy plus corporation) and one worldist internationalism, has been the ideological engine in the management of World War II, involving in the project also the 'communist' wing of liberalism. The end of the war has been also the end of the alliance of the world center and the communist world 'left,' at the origin of the very notion of united nations.'American liberalism' stood this time on the defensive and in the process of cold war the two worldist vision ended in a prevailing anticommunist liberalism.

Before coming to this critical phase of 'American liberalism' there had been a long period of great hopes, nourished by the faith in the possibility of

14. This is probably the meaning of the model of liberalism offered by Talcott Parsons, The Structure of Social Action, New York 1937. Parsons drew up for the Encyclopaedia the entry Society. a New Deal for the world? ${ }^{15}$ Under the guide of the Democrats, during the crucial twenty years that determined the assumption of hegemonic functions, United States on the one hand 'pursued welfare' state policies, which also aimed at extending civil liberties, while on the other hand it promoted an active foreign policy supporting world development,' meant to maintain a division of labor suitable to US interests. ${ }^{16}$

Initially, this policy presented itself with its 'progressive' face, thanks to the manifest American supremacy in terms of organizational development. The conflict would emerge mainly as a consequence of the resistance of some semiperipheral countries, first of all USSR, to accept as obvious the American hegemony. Hence the start of a confrontation among 'systems,' shortly afterwards denominated 'cold war.' This conflict put aside for a while the firm anticolonial action, aimed at reducing or eliminating the commercial hunting preserve of European colonial powers.

Cold war was probably the consequence of the obstacles the Soviet system, made possible by Yalta settlements, claimed to impose on free trade, threatening to extend to other countries its neo-mercantilism. After the Revolution, Lenin's Russia found herself sharing with Wilson the anticolonial component of the liberal vision, that become the central nucleus of Third International rhetoric. Nevertheless, the formula of 'socialism in a sole country' or later in a sole bloc,' legitimated by the sub-imperial role US assigned USSR after the war, represented a serious limitation to the liberty of action of the corporations.

Therefore, notwithstanding the holding out of the more coherent universalists, trained in the spirit of a 'New Deal for the world,' many liberals were persuaded to side with the anti-Soviet and anticommunist front, ${ }^{17}$

15. See Jason Berger, A New Deal for the World: Eleanor Roosevelt and American Foreign Policy, New York 1981. F. D. Roosevelt's wife, on special mandate by Truman administration, played a crucial role in the drafting and passing of 1948 Universal Declaration of Human Rights.

16. The various phases of this process mark Truman's administration, objectively forced to manage the crisis of one worldism and the retreat on McCarthyism. See Alonzo L. Hamby, Beyond the New Deal: Harry S. Truman and American Liberalism, New York and London 1973.

17. The union of Americans for Democratic Action well illustrates the essence of this position, characteristic of many intellectuals in the Democratic Party, to become 
thus reviving old isolationist dispositions in US opinion. In turn, western European countries, devoid at that time of any autonomy, found themselves engaged in containing communism, losing at the same time even the mere appearance of their sovereignties.

During the cold war years, just while the operation of politological Americanization of the world was starting, the historiographic approach of the 'vital center' established itself. This approach was based on the idea that the USA was a vital center of values, developing itself like a liberal spiral,' nearly a bound-to-happen constitutive process. Around this center was already acting the consensus of the major political forces, from the Left to the Right. ${ }^{18}$ However, this model, elaborated by the democrat historian Arthur Schlesinger Jr., which seemed consistent with the actual American praxis, was not to be exported out of the now hegemonic center of the world-system.

From the fifties on the differences among the core countries of the world-economy on the one hand and between them and the semiperipheral and peripheral ones on the other, became increasingly clear. Hegemonic country's liberalism was too limiting for other core countries and substantially impracticable in semiperipheral countries. Nevertheless, the United States won the war, imposed liberal political systems on Germany and Japan and urged or sustained similar systems in all other countries, starting the politological Americanization of the world that in fact ended with the final delegitimization of the Soviet system.

Peripheries could only make experiments' of liberalism, concealed with rhetoric. Differences moreover derived from the relative locations in the world division of labor, determining the so-called 'strategies of development.' Those strategies were implied in the one worldist projects of a world New

later the nucleus of Kennedy administration; see Steven M. Gillon, Politics and Vision: The ADA and American Liberalism, New York 1987. On the other hand, reached more or less visceral anticommunism also men like Berle andeven Henry Wallace, the leader of PCA (Progressive Citizens of America); see Norman D. Markowitz, The Rise and Fall of the People's Century. Henry A. Wallace and American Liberalism, 1941-1948, New York 1973. See also Richard H. Pells, The Liberal Mind in a Conservative Age. American Intellectuals in the 1940s and 1950s, Middletown 1989.

18. See Stephen P. Depoe, Arthur M. Schlesinger, Jr., and the Ideological History of American Liberalism, Tuscaloosa and London 1994.
Deal and were also considered, in the form of technical assistance policies, as part of the Democratic Party's political programs, from the very F. D. Roosevelt. The notion of technical assistance is probably to be connected to the policies of the big Foundations, aiming at creating the infrastructure and market opportunities in every section of the world.

American hegemony, which made possible the Wilsonian scheme of the League of Nations, after the war determined various interests, above all in the semiperipheries and peripheries of the world-system. The composition of the differences nevertheless assumed the character of a reduction of the gap in a unique world. US social science, in its more recent form of 'area studies,' had to acknowledge the inadequacy of the export of liberalism without development. This awareness took in the fifties the general form of 'modernization theory,' and ended in Kennedy's policies for Latin America (the Alliance for Progress), Africa and the rest of the world.

Those doctrines, founded on the principle of the establishment of national liberalisms in all countries, 'new' or developing, have been attacked and denounced as a rationalization of the interests of the core countries of the world-economy, that presupposed inalterable power relations. In different parts of the system started a criticism of the 'world' of nation-states sanctioned by the organization of United Nations. Moreover it was clear that the United States, if only to have a secure interstate system, was ready to renounce liberal coherence of their allies and some time to support the overthrowing of more liberal regimes, in favor of 'loyal' regimes. ${ }^{19}$

Under the pressure both of world Left and world Center, the principle of self-determination of peoples knitted to the principle of economic development. Gradually it started a process of criticism of 'modernization,' put forth by both radical and definitely moderate positions. The result of this process was the refusal of 'American liberalism,' mainly seen as 'corporate liberalism.' Criticism made use not only of Marxist schemes. Rather, it ended up in an involvement of those schemes in a more general criticism of liberal-Marxism, in the end the ideological underpinning of the very phase of American hegemony in the world system.

19. This is the message elaborated by politologist Samuel Huntington, Political Order in Changing Societies, New Haven 1968. 
A new social theory was needed. In the United States itself, at the center of liberal one worldism, by then became a stronghold of modernization functionalists, New York and Columbia University, Immanuel Wallerstein and Terence K. Hopkins formed a nucleus first of resistance and later of systematic elaboration of the approach now labeled world-systems analysis. ${ }^{20}$

In this approach various components of 'American liberalism' cohabit: the values of 'legislation oriented to the individual,' the acknowledgement of the normal character of the capitalism of giant corporations, and internationalism. To this a refusal is added to admit the nation-state as a primary organizational value, to be replaced with an 'historical' analysis and interpretation of the world division of labor, seen as world-economy and modern world-system.

The central concern of world-system scholars was now the problem of world inequality, always the focus of all the leftist versions of the liberalMarxist paradigm, become after the war a general problem of the major international organism, the UN. It was not clear if this new situation should have led to the elaboration once again of a 'new liberalism' or it was time for a new system of norms and values untied to the matrix of the European world-economy.

The struggle against inequality derived from the social relation between capital and labor, seen by the liberal-Marxist paradigm as a prerequisite for the achievement of substantive democracy, kept its appeal, but it was increasingly clear that it was an impracticable goal without eliminating inequality among collectivities located in a systemic division, between center, semiperiphery and periphery. ${ }^{21}$

It must be stressed that in the construction of the new historiographic apparatus Wallerstein seems to incorporate and to bridle the voluntarism of liberal-Marxist movements of the sixties in an objective structure of cyclical rhythms and secular trends, which we can not ignore if we want to be able to guide social change.

20. For more details, see Orlando Lentini, La scienza sociale storica di Immanuel Wallerstein, Milan 1998.

21. For the historical picture of this process see Immanuel Wallerstein, The Modern World-System I: Capitalist Agriculture and the Origins of the European World-Economy in the Sixteenth Century, New York: Academic Press, 1974.
Acknowledging the world nature of the constitutive process of the modern world-economy, historical social science has now the possibility to develop its analytical categories as a function of the new holism, making clear the limits of modernization theory. From this revision emerged even a new historiography of liberal institutions, now seen as the result of the formation both of a geopolitics and a geoculture of the world-system. ${ }^{22}$

Liberalism was now conceived not only as the vital center of the values of the hegemonic country, but also as the constitutive nucleus of the geoculture already since English hegemony. With this vital center march side by side both conservatism and 'socialism' (or progressivism), on common grounds. System dynamics have a common nucleus of organizational values, and it is only a matter of deciding which tactics would bring them into operation.

The ultimate liquidation of two worldism seems to confirm this interpretation of the vital center of values on a world scale, which besides tends to identify with the UN ideology. If the world 'vital center' played its role, it is nonetheless uncertain how can it last as the nucleus of geoculture with the demise of the Soviet system, so we speak also of a coming defeat of 'liberalism. ${ }^{23}$

Western imaginary and the ones of other 'worlds' always found themselves in a dynamics of opposition. Inside the world-economy this opposition showed itself both as a confrontation among nation-states as well as among alternative 'social classes.' Nevertheless, the reduction to system brought by a unique division of labor, determined also a new imaginary with a common technical content and differentiated 'values' and 'culture', reproposing old oppositions and creating new ones.

The 'new historical social science' had now to reformulate its 'structure of the whys,' beginning from asking not which the nature and cause of the wealth of the nations is but how this historical system functions. The dynamics of the system had been widely investigated by the liberal-Marxist paradigm as 'history and political economy of the capitalist system.' Dynam-

22. Immanuel Wallerstein, Geopolitics and Geoculture. Essays on the changing world-system, Cambridge: Cambridge University Press, 1991.

23. Immanuel Wallerstein, After Liberalism, New York: The New Press, 1995. 
ics were seen as the result of entrepreneurial voluntary effort, which created a market network increasingly expanded to become a world market, with the support of state apparatuses of different capitalist groups.

Now on the contrary it is requested to acknowledge that these dynamics are not universalistic but relative and historical, with core countries being able to command world labor and world markets, and among them a hegemonic country imposing the organizational principles. To incorporate in the historiography of world Left the normality of the hierarchical settlement of the world-system has been probably the major task of the approach elaborated by Wallerstein and Hopkins at the end of the sixties.

The 'one world' and its 'cultural' variations could not indeed ignore the deep inequality of the division of labor' of the world-system. This seems to be the key problem of the ethically oriented world historical social science, that is oriented according to liberal values, but the real problem is to better understand and manage the historical dynamics of the system.

The liberal-Marxist paradigm foresaw a transition towards a new system, determined by the explosion of the contradiction between capitalist social relations and development of productive forces. The new coming paradigm should ask himself how plausible the role ascribed to this contradiction is, since productive forces seem to find their way out even, and probably mostly, thanks to capitalist social relations. Transformation of the world in an arena for the economic acting of big corporations produced early in this century the 'corporate liberalism,' at first as an American phenomenon and later as a world phenomenon.

During the rising phase of the process, from the twenties, a very strong reaction to this world of giant corporations was the pluralist one by Brandeis, Laski, Frankfurter, reaction immediately incorporated by the world liberal Left and later by a section of the Marxist Left. What's clear is the prevailingly rhetorical meaning of this pluralism, as the various American administrations, besides 'pragmatic,' have always been definitely 'corporate.'

Therefore the option between 'corporate liberalism' and pluralism of 'small is beautiful'was above all a concession to the pluralist imaginary, while clearly leads to the problem of which pool of large corporations had the greatest power. The issue arose of a different division of the spoils. 'Corporate liberalism' is the deep nucleus of the new system of norms and values that imposed itself during American hegemony. How much of this 'corporate liberalism' entered into the European organizational imaginary, as well as the Japanese or the 'tigers of Asia's' one? How the transnationalization made normal the biological and cultural hybridization, legitimating its value in the world Charter of rights.

It is manifest that American 'corporate liberalism' coined a type of internationalism, practical one worldism, that did not coincide with the rhetorical one worldism destined to become the ideology of the United Nations and other international bodies. The new practical one worldism requested by an international community whose interstate system presupposes the principle of 'one country, one vote,' can not ignore the reality of an axial division of labor.

World-systems analysis has to face today the objective dominance of 'corporate liberalism,' keeping at the same time the pluralist option. This option implies organizational projections based on liberty rights of both single and variously associated subjects. Such rights can be guaranteed by establishing a modus vivendi between strong economic powers and citizens, but they are a mere petition of principle if there is not wealth to share.

The fulfillment of more 'democracy/equality' can be both an intermediate goal to be pursued through reforms and short steps, and an opportunity offered by a possible crisis of transition, which by placing movements in the presence of a bifurcation of choices, favors collective mobilization towards a 'new system.'

The ideology of a 'new system,' a futuristic one, seems to me to be a mobilizing organizational projection, fully in line with the schema of rightsliberty which forms itself early in the history of capitalist system. The difference between statu nascenti liberalism and this liberalism of the 'new system' is the latter's absoluteness, as far as there isn't democracy/liberty for a single individual if it is not for everybody, and there is not democracy/equality for one collectivity if it is not for all the collectivities.

The geoculture of the world-system, with its one worldism and its libertarian nucleus of value, not only seems to be able to survive the system that created it, but also to be the basis of the possible new. The great world religions, international bodies, single countries and human groups are in the midst of a re-elaboration of their systems of things to believe and things to do (credenda and agenda) in function of the new 'universal' nucleus of values arisen from the phase of American hegemony.

And it seems that it is not the first time it happens. 